\title{
Hypervitaminosis D Following Overdose in a Patient with SLE
}

\author{
Roy $\mathrm{K}^{1}$, Basu $\mathrm{S}^{2}$, Kundu $\mathrm{R}^{3}$, Das $\mathrm{J}^{4}$
}

${ }^{1}$ Dr. Kakali Roy, MBBS, Post graduate trainee of Paaediatric Medicine, ${ }^{2} \mathrm{Dr}$. Surupa Basu, MBBS, MD, Head of the Department of Biochemistry, ${ }^{3} \mathrm{Dr}$. Ritabrata Kundu, MBBS, $\mathrm{MD}$, Professor of Paediatric Medicine, ${ }^{4} \mathrm{Dr}$. Joydeep Das, MBBS, MD, Assistant Professor of Paediatric Medicine All from the Institute of Child Health, Kolkata, India.

Address for correspondence:

Dr. Kalki Roy

E-mail:kakaliroy.nrs2007@gmail.com

\section{How to cite \\ Roy K, Basu S, Kundu R, Das J. Hypervitaminosis D Following Overdose in a Patient with SLE. J Nepal Paediatr Soc 2016;36(2):196-197.}

doi: http://dx.doi.org/10.3126/jnps.v36i2.14847

This work is licensed under a Creative Commons Attribution 3.0 License.

\section{(c) (7)}

\begin{abstract}
Vitamin D supplementation has come under lime light and is being prescribed randomly. Often physicians prescribe high doses of Vitamin D. Overdosing may be dangerous if not supervised or followed up. We are presenting one child with all features of hypercalcemia due to hypervitaminosis $D$ following overdose. Doctors should be cautious during prescribing high dose of Vitamin D.
\end{abstract}

\section{Introduction}

itamin D (Vit-D) is a fat soluble vitamin and only vitamin which is produced endogenously at skin in response to ultraviolet B-light (290-320 nm) ${ }^{1}$. It is present in few foods, mainly fish. It has many beneficial effects but excessive Vit-D following excessive overtreatment can cause toxicity which is injurious and even may result death. We are reporting a case of hypervitaminosis- $D$ in a girl with SLE after excessive intake of vitamin D supplementation for bone pain.

\section{The Case}

Seven year old girl presented with joint pain for which a local doctor had prescribed Vit D 60,000 IU twice a month. But, due to clerical error by dispensing chemist or caregiver, she instead received the dose twice a day. On day 27 of medication, she presented to us with severe bone pain and all features of hypercalcemia like polydypsia, polyuria and constipation. She had already received a cumulative dose of 32.4 lakhs $\left(=1,20000{ }^{*} 27\right)$ IU of cholecalciferol.

On investigation serum calcium was $12.2 \mathrm{mg} / \mathrm{dl}$, SrVit-D was 400 $\mathrm{ng} / \mathrm{ml}$. Further evaluation showed ionised Ca $1.5 \mathrm{mmol} / \mathrm{L}$, albumin $4.1 \mathrm{mg} / \mathrm{dl}$, Phosphate $5.29 \mathrm{mg} / \mathrm{dl}$, alkaline phosphatase $151 \mathrm{U} / \mathrm{L}$ and parathyroid (PTH) $10 \mathrm{pg} / \mathrm{ml}$. Finally on investigation the cause of joint pain was diagnosed as SLE.

Vit D supplementation was stopped and hypercalcemia was treated by rehydration with normal saline, and intravenous frusemide. Repeat Ca level on third day of admission showed further increase to $13 \mathrm{mg} / \mathrm{dl}$. Thereafter Inj. Zoledronate (Bisphosphonate) intravenous infusion was started. On day 7 , symptoms subsided and $\mathrm{Ca}$ was $9.7 \mathrm{mg} / \mathrm{dl}$ while Vit-D was $315 \mathrm{ng} / \mathrm{ml}$ with normalisation of other biochemical parameters. 


\section{Discussion}

Vitamin $D$ is essential for calcium homeostasis and bone mineral metabolism. It is recommended for the prevention of rickets and bone loss, optimum bone mass formation. Additionally it has potential extra skeletal effects on the neuromuscular and immune system ${ }^{2}$. Most common cause of hypervitaminosis D is exogeneous intake either in the form of excessive supplementation of food and multivitamin or intake of over the counter pharmacological preparation of Vit $D$. The RDAs (recommended dietary allowances) is age specific and is between 400 I.U.to 800 I.U. for pediatric age group. Upper level of tolerance is between 1000$2000 \mathrm{IU}^{3}$. Where our patient was getting 1,20,000 IU per day which is almost 60 times more than maximum tolerance level.

Cholecalciferol $[25(\mathrm{OH}) \mathrm{D}]$ is the major form present in circulation and it is the best indicator of body Vit-D status. Serum 25(OH)D levels above $150 \mathrm{ng} / \mathrm{ml}$ is considered as toxic ${ }^{4}$. Vitamin $D$ increases serum $\mathrm{Ca}$ and phosphate by increasing absorption from gut and reabsorption from kidney, and mobilising bone mineral. Signs and symptoms of hypervitaminosis $D$ because of hypercalcemia are irritability, anorexia, constipation, polyurea, hypotonia and on long standing case it may result nephrocalcinosis and chronic renal failure.

The possible hypothesis of Vit-D toxicity involves increased Vit-D metabolites which reach the nucleus of target cell and cause exaggerated gene expression. Most available preparations contain calcidiol $[25(\mathrm{OH})$
D] and following overdose blood level increases and exceed Vit-D binding protein and binding capacity and 'free 25, $(\mathrm{OH}) \mathrm{D}$ ' enters the cell where directly affect gene expression ${ }^{5}$.

Treatment includes discontinuing intake of vitamin $D$ and calcium and management of hypercalcemia. Hydration is maintained strictly as hypovolemia may be present which increase non enzymatic absorption of $\mathrm{Ca}$ from proximal convoluted tubule. Loop diuretic inhibits absorption of Ca from loop of Henley. Majority of patients improves with this treatment. In unresponsive cases, Bisphosphonate is considered which works by inhibiting osteoclastic activity and thus inhibits bone resorption (which is the dominant mechanism of hypercalcemia in hypervitaminosis D). Our patient did not show clinical or biochemical improvement with initial therapy but improved after zolidronate infusion due to persisting hypervitaminosis $D$ being stored in the fatty tissues and liver6. Glucocorticoid that was given to our patient for treatment of her primary problem of SLE also has a known action of decreasing $\mathrm{Ca}$ absorption from gut by blocking calcitriol activity?

\section{Conclusion}

Prescribing Vit-D is now rampant even for milder symptoms without much awareness and concern for the toxic effects. Administration of Vit-D should be supervised. Doctors should be cautious about dosing and parents should be well counselled about potent side effects of overdosing. Therapy should be followed up with repeat assessments.

\section{References}

1. Holick MF. Environmental factors that influence the coetaneous production of vitamin D. The American Society for Clinical Nutrition.Am J ClinNutr1995;61(3):638S-645S

2. Farhat A,Mohamadzadeh A, Sayedi SJ et al. A case report of hypervitaminosis $D$ in 2 months old infant. Indian J Neanatol 2013;4:38-40

3. Ross AC, Taylor CL, Yaktine AL, et al. Dietary Reference Intakes for Calcium and Vitamin D. Washington (DC): National Academies Press (US);2011.Available at: https://www.ncbi.nlm.nih.gov/ books/NBK56058/

4. Misra M, Pacaud D, Petryk A, Collett-Solberg PF, Kappy M. Vitamin D deficiency in children and it's management: Review of current knowledge and recommendations. Pediatrics 2008;122:398-417.

5. KoulPA,Ahmad SH, Ahmad F et al. Vitamin D Toxicity in Adults: A Case Series from an Area with Endemic Hypovitaminosis D. Oman Med J 2011;26:201-204

6. RosenstreichSJ,RichC, Volwiler W. Deposition in and release of vitamin D3 from body fat: evidence for a storage site in the rat. J Clin Invest 1971;50(3):679687

7. FucikRF,KukrejaSC,Hargis GK et al. Effect of Glucocorticoids on Function of the Parathyroid Glands in Man.J ClinEndocrinolMetab2009;40(1):152-5.DOI: http://dx.doi.org/10.1210/jcem-40-1-152 